\title{
Juridical Study of Application for Rights with Grant Proof Seal for Minors Under Goverment Regulation (PP) No. 24 of 1997 on Land Registration
}

\begin{abstract}
Suyahmin $^{1}$, Euis Listianti ${ }^{2}$ and Amin Purnawan ${ }^{3}$
Abstract. Grants should be made in written form of the Public Notary. Grants will not be made by a Notary who do not have the force of law, they are subject to the customary law may be made under the hand, but the process must be made with the Land Office PPAT deed. In the implementation of the grant, the subject must be an adult (legally competent) so that it can perform its own legal actions because he has the right and obligation in full. The purpose of this study was to analyze the Strength of the Land Law with Proof Seal for Minors under PP 24 of 1997 as well as obstacles and solutions. The research method used juridical empirical approach, with qualitative descriptive data analysis techniques. The results of the research community who received land rights that have been acquired through a grant should make efforts to transition of property rights over land rights in accordance with the procedures and requirements are clear, whose goal in order to have certainty and legal protection for land-rights holders. But in this case the donee legal subjects are people who are still legally minors who have not been capable of doing a legal act.

Keywords: Land Registry; Land Grant; Minors.
\end{abstract}

\section{Introduction}

Literally means awarding grants, whereas according to the terms of grant giving something to someone for free, without expecting anything as a sign of affection. Grant is a gift that is done, either within the family or with others committed when they were alive or penghibah was still alive.

Legal origin of grants is permissible or allowed. However, based on the conditions and the role of the giver and the recipient of the grant could be mandatory, forbidden and permissible.

$$
\text { هن ابن عباس كاسئ رضي الله عنهما: أ ن رسول الله صلى الله عليه وسلم قال: العائد في }
$$

This means: "From Ibn Abbas RA, that the Prophet Muhammad. said, 'People who withdraw its grant as people who lick back vomit. "f

The land grant was given by one person to another with no compensation whatsoever and carried out voluntarily, without any counter-performance of the recipient administration, and the administration was carried out at the time of the donor is still alive. This is different with a will, which will be given after the pewasiat died. ${ }^{5}$

Understanding grant also provided for in article 1666 of the Civil Code, which grant is divulging agreement, where the Penghibah at the time of her life freely and irrevocably

\footnotetext{
${ }^{1}$ Student of Master of Notary Law Faculty of Law, Universitas Islam Sultan Agung email suyahmin12@gmail.com

2 Students of Master of Law, Faculty of Law, Universitas Islam Sultan Agung email elistianti19@gmail.com

${ }^{3}$ Lecturer in Faculty of Law UNISSULA Semarang

${ }^{4}$ Al-Hafizh Ibnu Hajar al-'Asqalani 2009 Terjemah Bulughul Maram At-Tibyan Solo p.430

${ }^{5}$ Chairuman Pasaribu dan Suhrawardi K. Lubis 1996 Hukum Perjanjian dalam Islam cetakan Kedua Sinar Grafika Jakarta p.113
} 
submit some object for the purposes of the grant recipients to take delivery of it. The law does not recognize other grants in addition to grants among people who are still alive.

Before the birth of the PP 24 of 1997, for those who are subject to the Civil Code grant letter will be made in written form of the Public Notary. ${ }^{6}$ Letters will grant that was not created by the Notary does not have the force of law. They are subject to the customary law may be under hand, but the process must be made with the Land Office PPAT deed. ${ }^{7}$ After the birth of the PP 24 of 1997, every grant of land should be done with a PPAT deed. ${ }^{8}$ Acquisition of land grants and the grants will transition should be registered there to in the local Land Office, as a means of securing the land grant.

Inaccuracy of the Land Office in issuing fake certificates from donations often occur because not examine whether the grants actually made by PPAT. As a result of a land dispute with a fake certificate sprung from donations. Fixity, certainty, and the veracity of the information contained in the deed of the land grant is critical to the process of registration and protection of land rights for the grantor, the heirs of the grantor and grantee. Consequently, PPAT in addition to be responsible for the certainty and truth of the deed of grant, are also required to submit certificates and other warkah to the Land Office.

The land registry is essentially intended to grant certain rights to the landowner. The issuance of a certificate giving a sense of security to landowners of their rights on the land. In order to provide legal certainty to all holders of the land, the land certificate serves as proof that strong. A land certificate as proof of the applicable evidentiary tool of the physical data and juridical data contained in it, as long as the data is in accordance with the data contained in the measurement certificate and land book. One of the problems is closely related to legal certainty in land registration is a matter of proof.

In-law explained that each person can be the subject of the law, but according to the provisions of Law no legal subjects imperfect means that legal subjects had only the will, but not being able to pour his will in legal acts, those that are immature / minors, adults but not able to do (crazy), and a woman in marriage. ${ }^{9}$

Regarding the subject of law is not perfect, that is, people who have not adult, according to Article 330 of the Civil Code are those who have not attained the age of 21 years old and had never been married before, while women in marriage since confirmed SEMA No. 13 of 1963, the position of women in marriage are considered competent according to the law, it is in accordance with the provisions of Article 31 Act No. 1 of 1974 on Marriage.

Civil law departs from the principle, that for the fulfillment and implementation of interests, the person is given the freedom to act according to his will, especially on wealth. They are, in principle, be given the freedom to take possession of it, against the freedom, maker of the Act provides among other restrictions related to age, which contains elements of protection.

All of them are related to skills issues acted within the law. To receive a right, allowed him immature, but he must be represented by a parent or guardian. Wali here has a wealth of functions take care of children who are under their supervision as well as possible and be responsible about the losses incurred because of poor maintenance. In the case of transition given to minors and responsibilities of a trustee then of the role and functions of institutions Heritage Hall (BHP). Heritage Hall (BHP) is the executor in the field of inheritance law enforcement in the Ministry of Justice and Human Rights. These

\footnotetext{
${ }^{6}$ Article 1005 Book of the Civil Law

${ }^{7}$ Effendi Perangin 1990 Mencegah Sengketa Tanah cet. -2 Rajawali Jakarta p.46

${ }^{8}$ Article 37 paragraph (1) and Article 39 of Government Regulation No. 24 of 1997 on Land Registration

${ }^{9}$ R. Subekti 1994 Pokok-Pokok Hukum Perdata PT. Internusa Bandung p. 341
} 
institutions not only look after the interests of orphans and children who are minors, In granting the rights, especially against objects remains inseparable from the role Deed Official Land, it means that the procedure transition requires an authentic deed made Deed Official Land, because if it is not done then the transfer of rights is void, otherwise intermediate goods move does not require authentic certificate, this can be done by direct delivery to the recipient the right or to third parties who accept the transfer of rights in the name of the assignee, as described in Article 1682 Jo Article 1687 of the Civil Code.

Likewise, according to PP 24 of 1997 that the transfer of land and bendabenda on it made by PPAT deed. The transfer of land from the owners to the recipient along with the submission of a juridical (Juridische Levering), a submission must meet the formality of law, including eligibility, made through the established procedure, using documents, created by / before PPAT. ${ }^{10}$

The grant of land will also result in the transfer of rights to the land. To obtain the land rights PPAT deed then it must get through several stages of the procedure. So what if the grantee is still included minors, whereas children who are minors are included the subject of law is not perfect. These problems become more interesting to study entitled "Juridical Study of Application For Rights With Proof Seal With Grants For Minors Under No PP. 24 of 1997 on Land Registration".

The research method used juridical empirical approach. Mechanical collection of legal materials in this study is the engineering study of literature (study document) is done by collecting (inventory) legal materials related to the problems in research, data analysis technique used is descriptive qualitative technique.

\section{Results and Discussion}

\subsection{Strength of the Land Law with Proof Seal Grant}

Article 37 PP 24 of 1997 Paragraph (1), "The transition of land rights and ownership of the apartment units through purchase, exchange, donation, inclusion in the company and the legal act of transfer of any other rights, except assignment through auction, can only be registered if evidenced by a deed made by PPAT authorized under the provisions of the legislation in force. "11

In effect, any rights to land should be registered. The purpose of registration is to obtain a title deed. Title deed has its own principle of interests and benefits, including:

- As evidence that the holder or the person named on the title deed is the person entitled to the land in question.

- Land certificate is evidence of land rights of the most powerful.

land grantconstitutegiving one person to another with no compensation whatsoever and carried out voluntarily, without any contra recipient of a gift, and the gift giver took place at the time was still alive. This is different with a will, which will be given after the pewasiat died. ${ }^{12}$

In article 1666 Book of the Law Maintenance registration data land was divided into five kinds of registration of transfer of rights, registration of loading rights, registration data changes, the registration of other lands, and issuance of certificate replacement, transfer of rights over land can be through sale, exchange, inheritance, merger or breakup, and grants. By this it is clear that any person who holds the right to land must register their land rights and keep the grant deed and certificate of land rights dispute that does not

\footnotetext{
${ }^{10}$ Abdul Kadir Muhammad 1994 Hukum Harta Kekayaan Cet. I Citra Aditya Bakti Bandung p. 55

${ }^{11}$ PP 24 of 1997 on Land Registration

${ }^{12}$ Adrian Sutedi 2009 Metode Penelitian Hukum Sinar Grafika Jakarta p.99
} 
happen in the form of a double certificate or certificate of loss of land rights in this regard through grants. Things that should not be done in the grant are as follows:

- The draft Civil Code Article 1668 states grantor should not foretell that he remains in power to sell or give to others an object that is included in the grant, the grant of such, just about the thing, to be considered as void.

- The Civil Code Article 1670 mentioned a grant is canceled, if it was made on the condition that the recipient of the grant will pay off debts or expenses other than those expressly states in the deed of grant alone or in a list attached to it.

- The draft Civil Code Article 1678 states "it is forbidden is the grant between husband and wife during the marriage".

Implementation of the transition of property rights through the grant must first be viewed ordinances grant. According to Section 1682-1685 of the Civil Code:

- Pursuant to Article 1682 of the Civil Code mentions nothing like a grant, except as specified in section 1687, can the threat canceled, it does in others by a notarial deed, which were originally kept by the notary.

- Pursuant to Article 1683 of the Civil Code mentions nothing like a grant binding the penghibah, or issuing a result of which, however, apart from day grant it with words that expressly accepted by the grantee itself or by a person with something authentic act by the donee it has been authorized to receive grants which has been the recipient of grants or be given to him kenudian day.

- Pursuant to Article 1685 of the Civil Code states grant to those minors under the authority of the parents must be received by the person making the power of parents. Grant to those minors who are under guardianship or people, must be received by the trustee, that for it to be authorized by the District Court.

- Pursuant to Article 1686 of the Civil Code states property rights to objects contained in the grant, even grant it has received legally, it is not passed to the recipient of the grant, in addition to the submission made pursuant to Articles $612,1613,616$, and so on.

In this case the legal subjects grant recipients are people who are still minors are legally not competent to perform legal acts, so that in performing a legal act must be represented or wali, if no guardian of the legal act performed minors deemed never existed as described in Article 1676 of the Civil Code.

Pursuant to Article 37 (1) PP 24/1997, grant land rights switchover occurs when registered using authentic deed made by PPAT, in this case is a Grant Deed. ${ }^{13}$ Given that lands were granted were registered also to the office of land (ownership rights to land grants have moved legally to the donee), then all the actions Grant-making adverse Grantee (in this case withdraw unilaterally land grant that has been established building) can be categorized as Torts, as stipulated in Article 1365 of the Civil Code. According to Article 1365 of the Civil Code, Grant-making unlawful act causing such damages may be recovered compensated by Grantees.

\subsection{Request Land Tenure with Proof Seal Grants for Minors Based on PP 24 of 1997 on Land Registration}

In-law explained that each person can be the subject of the law, but according to the provisions of Law no legal subjects imperfect means that legal subjects had only the will, but not being able to pour his will in legal acts, those that are immature / minors, adults but not able to do (mad) and woman in marriage. ${ }^{14}$

\footnotetext{
${ }^{13}$ http://www.humphreydjemat.com/post.php?id=80 Accessed October 102018 15:17 pm

${ }^{14}$ R. Subekti 1994 Pokok-Pokok Hukum Perdata PT. Internusa Bandung p. 341
} 
Regarding the subject of the law is not perfect, that is, people who are minors, pursuant to Article 330 of the Civil Code are those who have not attained the age of 21 years and have never been married before, while women in marriage since confirmed SEMA No. 13 of 1963 , the position of women in marriage is considered competent according to the law, it is in accordance with the provisions of Article 31 of Act No. 1 of 1974 on marriage.

To receive a right, allowed him immature, but he must be represented by a parent or guardian. Wali here has a wealth of functions take care of children who are under their supervision as well as possible and be responsible about the losses incurred because of poor maintenance.

Transition given to minors and under the responsibility of the trustee can not be separated from the role and functions of institutions Heritage Hall (BHP). Heritage Hall (BHP) is the executor in the field of inheritance law enforcement in the Ministry of Justice and Human Rights. These institutions not only look after the interests of orphans and children who are minors, but also take care of the treasure people under guardianship, property missing persons and their property are already bankrupt.

Need for Determination Mayor of the District Court in the manufacture of Sale and Purchase Agreements Notary / PPAT and registration of transfers of land rights in order to get legal protection for the recipient results of the acquisition of the sale and purchase of land and buildings as the holder of the rights to the new land, and for the sake of order administration land registration in accordance with Government Regulation No. 24 of 1997 on Land Registration.

\subsection{Obstacles and Solutions in the Process Request Land Tenure with Proof Seal Grants} for Minors under PP 24 of 1997 on Land Registration

Obstacles in the application process Land Tenure grants among others, unbeknownst Lurah or PPAT While recipients make the transition under arms, file giver or the receiver is not complete, inhibition of the issuance of the certificate of transition because of the fees charged to the recipient, the giver of elderly so that conditions to be prepared is not complete, the receiver lost evidence $C$ village when implementing the transition of property rights through the grant in the village and have to take care of returning to the old process, in terms of the object, that is a constraint related to the object inbetween that his land has been transferred and the deed of grant no but only using the letter $D$.

Solutions that can be taken to overcome these obstacles is the village that has the duty and function to serve the community and be an example for the community, should be more active if it is found that the shift of property rights through the grant under the arms and in the event of disputes arising then the village should act as witnesses and community mediators. ${ }^{15}$

\section{Closing}

\subsection{Conclusion}

Based on the description above, the conclusions of this research are:

- Strength of the Land Law grants under Regulation 24 of 1997, the transition grant land rights occurs when registered using authentic deed made by PPAT, in this case is a Grant Deed. Land donated were registered also to the office of land (ownership rights to land grants have moved legally to the donee), then all the actions Grant-making adverse Grantee (in this case withdraw unilaterally land grant that was standing

15 Chrismasco 2011 Pelaksanaan Peralihan Hak Milik Atastanah Melalui Hibah Di Kelurahan Jatibarang Kecamatan Mijen Kotasemarang Scription Faculty of Law Unnes Semarang. 
building) can categorized as Torts, as stipulated in Article 1365 of the Civil Code. According to Article 1365 of the Civil Code, Grant-making unlawful act causing such damages may be recovered compensated by Grantees If grantees are people who are still minors,

- Transition given to minors and under the responsibility of the trustee can not be separated from the role and functions of institutions Heritage Hall (BHP). Heritage Hall (BHP) is the executor in the field of inheritance law enforcement in the Ministry of Justice and Human Rights. The procedure requires a transfer is made the authentic deed Deed Official Land, because if it is not done then the transfer of rights is void. Need for Determination Mayor of the District Court in the manufacture of Sale and Purchase Agreements Notary / PPAT and registration of transfers of land rights in order to get legal protection for the recipient results of the acquisition of the sale and purchase of land and buildings as the holder of the rights to the new land, and for the sake of order administration land registration in accordance with Government Regulation No.

- Obstacles in the application process Land Tenure grants among others, unbeknownst Lurah or PPAT While recipients make the transition under arms, file giver or the receiver is not complete, inhibition of the issuance of the certificate of transition because of the fees charged to the recipient, the giver of elderly so that conditions to be prepared is not complete, the receiver lost village $C$ evidence when carrying out the transition of property rights through the grant in the village and have to take care of returning to the old process. Solutions that can be taken to overcome these obstacles is the village that has the duty and function to serve the community and be an example for the community,

\subsection{Suggestion}

- For people who have rights to the land acquired through a grant should make efforts to shift proprietary rights over the land in accordance with the procedures and requirements have been determined, although there Letter $D$ or $C$ village is also a proof of ownership but legal force would be stronger if The Make a deed of grant and continued into the certificate of land rights.

- For the Village Office in order to disseminate the importance of land ownership certificates as proof of the holder of land rights and the legal consequences, the effort does not occur on land rights disputes in the future.

\section{Bibliography}

[1] Al-Hafizh Ibnu Hajar al-'Asqalani 2009 Terjemah Bulughul Maram At-Tibyan Solo

[2] Ali Achmad Chomzah 2004 Hukum Agraria (Pertanahan Indonesia) Jilid 2 Prestasi Pustaka Publisher Jakarta

[3] Chairuman Pasaribu dan Suhrawardi K. Lubis 1996 Hukum Perjanjian dalam Islam cetakan Kedua Sinar Grafika Jakarta.

[4] Effendi Perangin 1990 Mencegah Sengketa Tanah cetakan ke-2 Rajawali Jakarta

[5] R. Subekti 1994 Pokok-Pokok Hukum Perdata PT. Internusa Bandung

[6] Abdul Kadir Muhammad 1994 Hukum Harta Kekayaan Cetakan I Citra Aditya Bakti Bandung

[7] Adrian Sutedi 2009 Metode Penelitian Hukum Sinar Grafika Jakarta

[8] R. Subekti 1994 Pokok-Pokok Hukum Perdata PT. Internusa Bandung

[9] Chrismasco 2011 Pelaksanaan Peralihan Hak Milik Atastanah Melalui Hibah Di Kelurahan Jatibarang Kecamatan Mijen Kotasemarang Scription Faculty of law Unnes Semarang 
Volume 5 Issue 4, December 2018

[10] Regulation No. 24 of 1997 on Land Registration

[11] http://www.humphreydjemat.com/post.php?id=80 